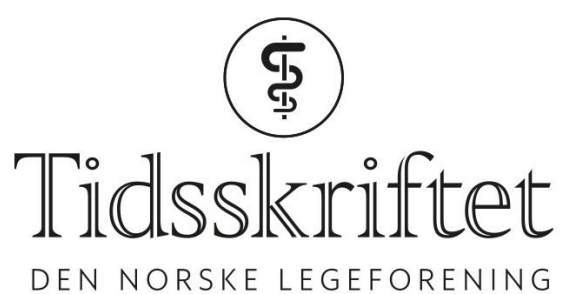

DEN NORSKE LEGEFORENING

\title{
Filleristet spedbarn eller ikke?
}

KOMMENTAR

\section{HANNA MARIA ENG}

E-post: hanna_maria_e@hotmail.com

Hanna Maria Eng er overlege i patologi.

Ingen oppgitte interessekonflikter.

Knut Wester stilte spørsmål ved om den medisinske dokumentasjonen som sakkyndige i dag vurderer som bevis på filleristing, er av tilstrekkelig vitenskapelig kvalitet til at den kan brukes som juridisk bevis for at filleristing faktisk har funnet sted (1). Videre spurte han om det dermed foreligger "skyld utover enhver rimelig tvil». Han trekker blant annet frem tilstanden benign ekstern hydrocephalus som tilstand som kan fremstå som en enkeltkomponent i den såkalte triaden. På bakgrunnen av forskningen han refererer til, virker det rimelig å stille spørsmål.

I et debattinnlegg og tilsvar av Arne Stray-Pedersen og medforfattere konkluderes det at kunnskapsgrunnlag i dag er godt nok (2), til tross for at en del forskning kan tyde på annet. I tillegg frykter forfatterne for at ensidig og unyanserte medieoppslag skal få store konsekvenser for barns sikkerhet og rettsvern fremover. Så vidt meg bekjent er innlegget forfattet av en gruppe hvor nesten alle har jobbet og blitt lønnet som sakkyndige.

Tanken slår meg: Ville ikke det viktigste her være å faktisk finne ut av om grunnlaget for vurderingene er gode nok? Dommer på eventuelt feilaktig grunnlag ville være katastrofalt. Jeg imøteser Westers planlagte forskningsprosjekt, som har til hensikt å gå gjennom grunnlaget for dommer i slike straffesaker ved norske domstoler.

Det er bra å stille spørsmål ved etablerte medisinske «sannheter». Sakkyndige besitter stor makt. Som kjent for flere er det dessverre et dårlig ytringsklima innen rettsmedisin i Oslo. Det er til ettertanke at det i det relativt lille fagmiljøet, som det norske rettsmedisinske miljøet representerer, ikke i større grad verdsettes at det stilles spørsmål.

\section{LITTERATUR:}

1. Wester K. Har et «filleristet spedbarn» alltid vært filleristet? Tidsskr Nor Legeforen 2018; 138. doi: 10.4045/tidsskr.18.0583. [PubMed][CrossRef]

2. Stray-Pedersen A, Møller C, De Lange C et al. Legers rolle ved mistanke om alvorlig barnemishandling. Tidsskr Nor Legeforen 2019;139. doi:10.4045/tidsskr.18.0922. [CrossRef] 